\title{
CYTOGENETIC CHANGES IN HUMAN LYMPHOCYTES INDUCED BY ALPHACHLORHYDRINE
}

TEODOROVIĆ RADISLAVA, STANIMIROVIĆ Z, RADENKOVIĆ-DAMNJANOVIĆ BRANA, VUČINIC MARIJANA, JANKOVIĆ LJILJANA, ĐORĐEVIĆ M and MIRILOVIĆ M

University of Belgrade, Faculty of Veterinary Medicine, Serbia

(Received 11 th May 2010

This paper deals with the results of the investigation carried out with regard to genotoxic properties of Alphachlorhydrine administered at doses of $7.5,15$ and $30 \mathrm{mg} / \mathrm{kg}$ of cell culture-human lymphocytes, during an exposition time of three days, under in vitro conditions.

The assessment of the genotoxic effects of the tested chemosterilants was performed on the basis of numerical and structural aberrations in three experimental groups, in addition to one control group for each dose.

On the basis of the obtained results it can be conculded that Alphachlorhydrine, administered in the abovementioned doses, induced genotoxic effects on human lymphocyte cells. The number of numeric aberrations increased with a dose increase, and the statistical analysis showed significant differences $(p<0.01)$ in relation to the control group, but not between the applied doses $(p<0.05)$.

Analysis of the obtained results demonstarted that a dose increase during the same exposition time, resulted in a statistically significant increase $(p<0.01)$ of structural aberrations in human lymphocyte cells; the highest level being achieved with the highest administered dose (30 mg/kg c.c.). As for Robertsonian translocations, there was a statistical significance with relation to the control group only in the case of the highest administered dose (30 mg/kg c.c.). Statistically significant differences $(p<0.01)$ were recorded between the $30 \mathrm{mg} / \mathrm{kg}$ c.c. and $7.5 \mathrm{mg} / \mathrm{kg}$ c.c. doses. Also there were statistically significant differences between the levels of gaps and fragments in comparison to Robertsonian translocations $(p<0.01)$; while the numbers of gaps and fragments were not significantly different.

Key words: Alphachlorhydrine, cytogenetic, genotoxic effects, hyman, lymphocytes

\section{INTRODUCTION}

The number of populations of rodents has constantly increased during the evolution, causing more and more damages, directly or indirectly, to human populations. Due to their obvious economic, epizootic and epidemiologic importance it is indispensable to undertake some efficient measures in order to 
control rodent populations, i.e. to reduce their populations to a safe level so that the health of men, domestic and wild animals is protected. The application of the existing mechanical, physical, biological and chemical methods intended for rodent control, has not yielded the expected satisfactory results, i.e. satisfactory effects have been achieved in smaller buildings, or in less invaded larger buildings.

More and more present rodent resistance to the existing rodenticides requires a constant effort to find new methods or new chemical agents in order to be able to satisfactorily control those rodent populations. Such are ready made baits made on the basis of chemosterilants, Alphachlorhydrine being the most frequently used one. Chemosterilants cause temporary or permanent sterility in these pests, either in both sexes, or individually (Eriksson et al., 1971). They can also inhibit, directly or indirectly, the growth and maturation of gametes, prior or after copulation, or prevent the union of the ovum and spermatozoon, as well as the implantation of the ovum in the uterus (Rex, 1970). In addition, they can suppress the sexual development of the young and cause irreversible sterility or death of the young ones due to lactation reduction in their mothers (Gao and Short, 1993).

As it has been proved that some pesticides-rodenticides, produced mostly on the basis of derivates of cumarin and INANDION (Soldatović et al.,1979, 1980, 1981; Kataranovski, 1985; Sofradžija et al., 1989; Vučinić, 1994; Stanimirović et al., 1997) cause cytological, mitotic and chromosomal aberrations, and that the available literature contains scanty data on genotoxic effects of chemosterilants, we undertook to investigate whether Alphachlorhydrine can induce genotoxic effects on human lymphocyte cells.

\section{MATERIAL AND METHODS}

The genotoxic effects of Alphachlorhydrine s. U-5897 (3-chloro-1,2propandiol) a highly efficient nonsteroid chemosterilant, were investigated in vitro.

For the studies, human lymphocites were treated with $7.5,15$ and $30 \mathrm{mg}$ Alphachlorhydrine per kg cell culture during exposure of 3 days. Mitotic activity and the appearance of structural and numerical aberrations were investigated. Chromosomal analyses were performed on cells fixed in Carnam solution and dissolved in $0.56 \% \mathrm{KCl}$ by the method described by Hsu and Patton (1969).

Cell culture humane lymphocytes were prepared by the method Evans and O'Riordan (1977).

The results obtained were analyzed Student's test (The Statgraphics 5.0Statistical Graphics Corporation, USA programme).

\section{RESULTS ADN DISCUSSION}

Table 1 contains the obtained results pertaining to the effect of Alphachlorhydrine (administered at doses of $7.5,15$ and $30 \mathrm{mg} / \mathrm{kg}$ c.c.) on human lymphocytes under in vitro conditions from the point of numerical aberrations. During the three-day treatment three experimental and one control 
Acta Veterinaria (Beograd), Vol. 60, No. 5-6, 619-624, 2010.

Teodorović Radislava et al.: Cytogenetic changes

in human lymphocytes induced by Alphachlorhydrine

group of cells were monitored. From 78 to 102 metaphase figures were examined in each experimental group, and 84 metaphase figures in the control group.

Table 1. Numerical aberration in human lymphocytes induced by Alphachlorhydrine

\begin{tabular}{|c|c|c|c|c|c|c|c|c|c|c|c|}
\hline \multirow{2}{*}{ Doses } & Investigated & \multicolumn{4}{|c|}{ Number chromosomes } & \multicolumn{3}{c|}{ Aneuploidy } & \multicolumn{2}{c|}{ Polyploidy } \\
\cline { 3 - 12 } & cells & $<46$ & $\%$ & 46 & $\%$ & $>46$ & $\%$ & Number & $\%$ & Number & $\%$ \\
\hline \hline K & 84 & 2 & 2.38 & 82 & 97.61 & 0 & 0.00 & 2 & 2.38 & 0 & 0.00 \\
\hline I & 102 & 8 & 7.84 & 88 & 86.27 & 6 & 5.88 & 14 & 13.72 & 0 & 0.00 \\
\hline II & 78 & 10 & 12.82 & 60 & 76.92 & 6 & 7.69 & 16 & 20.51 & 2 & 2.56 \\
\hline III & 94 & 21 & 22.34 & 61 & 64.89 & 9 & 9.57 & 30 & 31.91 & 3 & 3.19 \\
\hline
\end{tabular}

Investigated doses: $\mathrm{K}$ - Control group; I - $7.5 \mathrm{mg} / \mathrm{kg}$ c.c.; II - $15 \mathrm{mg} / \mathrm{kg}$ c.c.; III - $30 \mathrm{mg} / \mathrm{kg}$ c.

The diploid number of chromosomes in the control lymphocyte group reached $97.61 \%$, in aneuploid cells $2.38 \%$; whereas poliploid cells were not registered. The dose increase was accompanied with a decrease in the number of diploid cells - the lowest value of $64.89 \%$ being attained with the highest dose of $30 \mathrm{mg} / \mathrm{kg} \mathrm{c.c.} \mathrm{At} \mathrm{the} \mathrm{same} \mathrm{time,} \mathrm{the} \mathrm{number} \mathrm{of} \mathrm{aneuploid} \mathrm{cells} \mathrm{was} \mathrm{markedly}$ increased at the highest dose, the attained level reaching $31.91 \%$ of which the greatest part belonged to haploid cells (22.34\%). An increase in the dose, i.e. at the doses of $15 \mathrm{mg}$ and $30 \mathrm{mg} / \mathrm{kg}$ c.c. occurred an increase in the number of poliploid cells, up to the level of $2.56-3.19 \%$. This increase as a function of dose was statistically significant $(p<0.01)$. The incidences of changes in all the three applied doses in relation to the control group were also statistically significant $(p<0.01)$, except in the case of poliploidy when no significant statistical difference was recorded $(p<0.05)$.

The second part of the experiment refers to the effect of various doses (7.5 15 and $30 \mathrm{mg} / \mathrm{kg} \mathrm{c.c.)}$ of Alphachlorhydrine on human lymphocyte cells during the three experimental days with regard to the occurence of structural aberrations. Table 2 contains the results at the level of average mean values.

Table 2. Cytogenetical effects (structural changes) of Alphachlorhydrine on humans lymphocites (average values)

\begin{tabular}{|c|c|c|c|}
\hline \multirow{2}{*}{ Group } & \multicolumn{3}{|c|}{ Structural changes (\%) } \\
\cline { 2 - 4 } & Gaps & Fragments & $\begin{array}{c}\text { Robertson's } \\
\text { Translocations }\end{array}$ \\
\hline \hline K & 0.0 & 1.0 & 0.0 \\
\hline I & 3.5 & 6.5 & 0.0 \\
\hline II & 8.0 & 10.5 & 0.0 \\
\hline III & 10.5 & 12.5 & 2.0 \\
\hline
\end{tabular}

Investigated doses: K - Control group; I - $7.5 \mathrm{mg} / \mathrm{kg}$ c.c.; II - $15 \mathrm{mg} / \mathrm{kg}$ c.c.; III $-30 \mathrm{mg} / \mathrm{kg}$ c.c 
Each experiment was conducted on three experimental groups and one control group. Within each group, on the average 100 metaphase figures were examined. In the control groups gaps and fragments were recorded up to the level of $1 \%$; whereas Robertsonian translocations were not recorded. A dose increase, during the same exposition time, is accompanied with an increase in values of structural aberrations; the highest level being reached at the highest administered dose $(30 \mathrm{mg} / \mathrm{kg}$ c.c.). This increase as a function of dose was statistically significant $(p<0.01)$, except in the case of Robertsonian translocation where the statistical significance with regard to the control group was recorded only in the case of the highest administered dose $(30 \mathrm{mg} / \mathrm{kg}$ c.c.). Statistically significant differences $(p<0.01)$ were recorded between the $30 \mathrm{mg} / \mathrm{kg}$ c.c. and $7.5 \mathrm{mg} / \mathrm{kg}$ c.c. doses. Also, statistically significant differences between the levels of gaps and fragments, in comparison to Robertsonian translocations $(p<0.01)$ were recorded, while the numbers of gaps and fragments were not significantly different.

On the basis of the obtained results it can be concluded that Alfahlorhidirin in administered doses, during an exposition time of three days, can bring about damages to the genetic material. Cytogenetic changes were recorded also in other rodenticides (Sofradžija et al., 1989; Kataranovski, 1994; Stanimirović et al., 1997; Teodorović et al., 1999; Teodorović, 2004), as in many other substances used in veterinary medicine (Albertini et al., 2000; Stanimorović et al., 2003; Platet et al., 2004; Đelić et al., 2006). The majority of these investigations, similar to our experiment, was performed under in vitro conditions on human leucocyte cell cultures. Alphachlorhydrine, in addition to its genotoxic effects on genetic material, induces sterilization of male rats, temporary sterilization of guinea pigs and monkeys (Ericsson and Baker, 1970; Kirton et al., 1970; Ericsson et al., 1971) and has no effect on fertility of mice and rabbits (Ericsson, 1970).

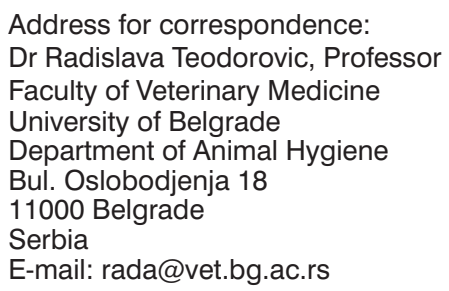

\section{REFERENCES}

1. Albertini RJ, Anderson D, Douglas GR, Hagmar L, Hemminki K, 2000, IPSC guidelines for the monitoring of genotoxic effects of carciogenes in humans, Mutat Res, 463, 72-111.

2. Đelić N, Spremo-Potparević Biljana, Marković Biljana, Živković Lada, Đelić Dijana, 2006, Cell cycle kinetics and cytogenetic change in human lymphocites exposed to ostradiol in vitro, 56, 37-48.

3. Ericsson RJ, 1970, Male antifertility compounds: U-5897 as a rat chemosterilant, $J$ Reprod Fert, 22, 213-22.

4. Ericsson RJ, Baker VF, 1970, Male antifertility compounds: biological properties of U-5897 and U-15 646, J Reprod Fert, 21, 267-9.

5. Ericsson RJ, Downing HE, Marsh RE, Howard WE, 1971, J Wildl Manage, 35, 3, 573-6. 
6. Evans HJ, O'Riordan ML, 1977, Human peripheral Blood lymphocytes for analysis of chromosome aberations in mutagen tests. Is mutagesiticity Test procedures (Ed. Kilbey) Elsivier/Noth Holland Biomedical Press, 261-74.

7. Gao Y, Short RV, 1993, The control of rodent populations, Oxford Rev Rep Biol, 15, 265-310.

8. Hsu TC, Patton JI, 1969, Bone marow preparations for chromosome studies, In: Bemirschke K (Ed). Comparative mammalian cytogenetics, Springer Verlag, Berlin Heikdelberg New York, 454-60.

9. Kirton KT, Ericsson RJ, Ray JA, Forbes AD, 1970, Male antifertility compounds :efficacy of U-5897 in primates (Macaca mulatta), J Reprod Fert, 21, 275-7.

10. Kataranovski D, 1985, Citotoksični efekat antikoagulantnih rodenticida na populacije vrste Rattus norvegicus BERK 1769 i čoveka, Magistarski rad, Centar za multidisciplinarne studije Univerziteta u Beogradu.

11. Kataranovski D, Kataranovski M, 1986, Efekti kumarinskih rodenticida na proliferaciju i varijabilnost humanih Thimocita, Zbornik radova, VII kongres biologa Jugoslavije, Budva, 320.

12. Kataranovski $D, 1994$, The toxicity of rodenticides in rats following topical application I LD 50 and LD 100 values and changes of selected serum and urine biochemical parameters, J Serb Chem Soc, 59, 787-95

13. Platet N, Cathiard AM, Gleizes M, Garcia M, 2004, Estrogens and their receptors in breast cancer progression a duel role in cancer proliferacion and invasion, Crit Rev Oncol Hematol, 51, 55-67.

14. Rex EM, 1970, Theory and potencial value of rodent chemosterilants, Word Health Organisation, WHO/VBC/ 70, 176, 1-4

15. Sofradžija A, Hadžiselimović R, Maslić E, 1989, Genotoksičnost pesticida, Svjetlost, Sarajevo.

16. Soldatović B, Janković D, Milosavljević S, Savić I, Kataranovski D, 1979, Dejstvo Rakumina 57 i Rosola na hormone sivog pacova, VIII simpozijum iz oblasti DDD, Ohrid, 4-6.

17. Soldatović B, Zimonjić D, Kataranovski D, Savić I, 1980, Citogenetički efekti Rakumina 57 i DDT-a na ćelije pacova Rattus norvegicus i čoveka, Zbornik radova II simpozijuma - DDD u zaštiti zdravlja ljudi, Beograd, 165-8.

18. Soldatović B, Zimonjić D, Haidovy MAN, Savić I, Kataranovski D, 1981, Mutageni efekti nekih rodenticida i insekticida konstatovani na ćeliji sisara, Zbiornik radova IX simpozijuma iz DDD i neškodljivog uklanjanja otpadne animalne tvari, Haludovo, 32-7.

19. Stanimirović Z, Vučinić M, Soldatović B, Marković B, 1997, Genotoxicity and potential hemosterilant effects of Rodol, Acta Vet (Beograd), 47, 237-46.

20. Stanimirović Z, Fišter S, Stevanović J, 2003, Analysis of sister-chromatid exchanges in cultured human lymphocytes treated with cymiazole hydrochloride, Acta Vet (Beograd), 53, 419-25.

21. Stanimirović Z, Todorović D, Stevanović J, Mladenović M, Janković Lj, Đorđević M, 2003, Influence of cymiazole hydrochloride on mitotic and proliferative activities of cultured human lymphocites, Acta Vet (Beograd), 53, 47-55.

22. Teodorović $R$, Soldatović B, Teodorović $V$, Mirilović $M$, 1999, The genotoxic effects of alphachlorhydrin in BALB/C strain, Acta Vet (Beograd), 49, 239-46.

23. Teodorović $R, 2004$, Cytogenetic changes in bone marrow and fibroblast cells of BALB/C laboratory mice induced by Mestranol, Acta Vet (Beograd), 54, 263-70.

24. Vučinić $M$, 1994, Uticaj kombinovane intragastrične aplikacije benzalkonijum-hlorida i varfarinnatrijuma na citogenetičke promene ćelija kostne srži i semenika laboratorijskih miševa, Doktorska disertacija, Beograd. 


\title{
CITOGENETIČKE PROMENE LIMFOCITA ČOVEKA INDUKOVANE ALFAHLORHIDRINOM
}

\author{
TEODOROVIĆ RADISLAVA, STANIMIROVIĆ Z, RADENKOVIĆ-DAMJANOVIĆ BRANA, \\ VUČINIĆ MARIJANA, JANKOVIĆ LJILJANA. ĐORĐEVIĆ M i MIRILOVIĆ M
}

\section{SADRŽAJ}

U ovom radu su izvršena ispitivanja genotoksičnih svojstava Alfahlorhidrina u različitim dozama: $7.5,15$ i $30 \mathrm{mg} / \mathrm{kg}$ kulture ćelija - limfocita čoveka, tokom ekspozicije od 3 dana, u uslovima "in vitro".

Procena genotoksičnih efekata, ispitivanih hemosterilanata, je vršena na osnovu numeričkih i strukturnih aberacija na tri eksperimentalne grupe sa po jednom kontrolnom za svaku dozu.

Na osnovu rezultata naših ispitivanja može se zaključiti da Alfahlorhidrin u testiranim dozama dovodi do genotoksičnih efekata na ćelijama limfocita čoveka. Broj numeričkih aberacija se povećavao sa rastom doze i statističkom analizom su utvrđene signifikantne razlike $(p<0,01)$ u odnosu na kontrolne grupe, ali ne i između primenjenih doza $(p>0,05)$. U slučaju poliploidija nije utvrđena statistički značajna razlika u odnosu na kontrolnu grupu $(p>0,05)$.

Analizirajući dobijene rezultate utvrđeno je da sa povećanjem doze pri istoj ekspoziciji dolazi do statistički značajnog $(p<0,01)$ povećanja broja strukturnih aberacija na ćelijama limfocita čoveka, pri čemu najviši nivo je postignut kod najviše primenjene doze (30 mg/kg c.c.). Kada su u pitanju Robertsonove translokacije statistička značajnost u odnosu na kontrolnu grupu utvrđena je tek kod najviše primenjene doze $(30 \mathrm{mg} / \mathrm{kg}$ c.c.). Statistički značajne razlike $(p<0,01)$ su zabeležene između doza od $30 \mathrm{mg} / \mathrm{kg}$ c.c i $7,5 \mathrm{mg}$ c.c. Takođe statistički značajne razlike između nivoa otvora i fragmenata mogu se uporediti sa Robertsonovim translokacijama $(p<0,01)$, dok se broj otvora fragmenata neće značajno promeniti. 